\title{
音声解析による睡眠時無呼吸症の判別法および予備群早期発見プロセスの提案
}

\author{
白砂 絹和*1，章 忠 ${ }^{* 1}$ ，戸田 浩*2，石川 康宏*3，阪口 龍彦*1，秋月 拓磨*2
}

\section{Proposal for Sleep Apnea Syndrome discriminating method and discovery process pre-SAS. \author{
Tatsuhiko SAKAGUCHI ${ }^{* 1}$ and Takuma AKIDUKI ${ }^{* 2}$ \\ ${ }^{*} 1,{ }^{2}$ Department of Mechanical Engineering, Toyohashi University of Technology \\ 1-1 Hibarigaoka, Tempaku-cho, Toyohashi-shi, Aichi 441-8580, Japan \\ ${ }^{*}$ Iryohojin Kosyokai Ishikawa Iin \\ 1-3-16, Honmachinishi, Chuo-ku, Saitama-shi 338-0004, Japan
} \\ Miyori SHIRASUNA ${ }^{* 1}$, Zhong ZHANG ${ }^{* 1}$, Hiroshi TODA ${ }^{* 2}$, Yasuhiro ISHIKAWA ${ }^{* 3}$,}

Received: 16 August 2018; Revised: 3 October 2018; Accepted: 6 November 2018

\begin{abstract}
This paper presents a discrimination method of Sleep Apnea Syndrome (SAS) and early detection of potential Sleep Apnea Syndrome (Pre-SAS) using sleep breath sound, by which each subject can take the required data for the diagnosis at home only with a voice recorder. Sleep breath sound of around two hours is analyzed statistically for detecting SAS patients. Long silence sections in the sleep breath sound and the biggest sound pressure typically occurred after them are compared for distinguishing Pre-SAS, SAS patients and non-patients. The k-means method is applied for classifying the above sound data. The proposed method drastically reduces the time and effort required for SAS diagnosis compared to the current medical approaches. Experimental results show the effectiveness of the proposed method, by which $100 \%$ accuracy of discrimination is achieved.
\end{abstract}

Keywords : Sound analysis, Multivariable analysis, Discriminant analysis, Clustering, Sleep apnea syndrome

1. 緒言

近年, 睡眠時無呼吸症 (Sleep Apnea Syndrome : SAS) の対策の重要性が指摘されている（国土交通省，2018，厚 生労働省，2018）.SAS は，睡眠中に呼吸が停止する疾病であり，診断済みの罹患者に未診断者を含めると，国民 の数パーセントに達するとの報告もある（SAS 診療国際提供サービス・ビジネス化検証コンソーシアム，2015） . 同罹患者の多くは合併症を伴い，成人病については国民の平均罹患率の約 $2 \sim 6$ 倍であり，さらには，適正な治療 を受けない場合，累積生存率が大幅に低いという報告もある（佐藤，2016，白濱，2015，塩見，2013）。SAS は自 覚に乏しく, 危機感も薄いため, 進行に気付かないケースも多い。また，医療機関から提示される検査報告書は， 専門用語と数字のみであり，被験者には理解が難しく，実感に欠ける懸念がある．現行の SAS の診断は，医療機 関が貸し出すポータブルモニターによる簡易検査，および一泊入院による終夜睡眠ポリグラフ検査があり，睡眠 時の呼吸の状態や心拍数, 酸素飽和度などの值をもとに診断をする（内田，2013）。これらを用いた SAS の研究 も行われている（Rachim et al.，2014，Emin et al.，2010）。しかし，両検査とも，被験者は身体に検査機を装着

No.18-00328 [DOI:10.1299/transjsme.18-00328], J-STAGE Advance Publication date : 14 November, 2018

${ }^{* 1}$ 正員, 豊橋技術科学大学 大学院工学研究科 機械工学系 (干441-8580 愛知県豊橋市天伯町雲雀笛 1 -1)

$*_{2}$ 豊橋技術科学大学 大学院工学研究科 機械工学系

*3 医療法人康昌会 石川医院（盯338-0004＼cjkstart埼玉県さいたま市中央区本町西 1-3-16）

E-mail of corresponding author: shirasuna@me.tut.ac.jp 
Shirasuna, Zhang, Toda, Ishikawa, Sakaguchi and Akiduki,

Transactions of the JSME (in Japanese), Vol.84, No.868 (2018)

するストレスがあり, 通常の睡眠を取れない問題が，医療学術的に指摘されている（富田，成井，2016）。簡易音 声レコーダなどを用いた，睡眠中のいびき音の解析による SAS の診断への検討や提案が行われている（Emotoa et al., 2017, Keong et al., 2008）が，実用化された例はまだ見受けられていない．そこで著者らは，医工学的な知見 から, 睡眠中の呼吸音データのみによる, 次のような SAS の判別法および予備群早期発見プロセスの提案をする. 1. SAS 予備群の発見は, 一般的に完治という概念のない成人病予備群の発見と予防医療に繋がる, 2. 睡眠中の呼 吸音（いびき音）による SAS 罹患者および予備群の判断は, 枕元に置く簡易音声レコーダを用いて容易に行える.

SAS の解析および判別に関する多くの研究は, 罹患者を対象としたものであり（Kaneshiro et al., 2016, Rachim et al., 2014, Koley and Dey, 2013, Emin et al., 2010), 本提案のように予備群も含めたものは, ほとんどない. 睡眠中の音声以外の計測データを対象としたものが主流である（Rachim et al., 2014, Emin et al., 2010）. また, 睡眠中の呼吸音データは長大かつ不均一であるため, 先行の SAS 音声解析の報告は, 解析対象部分を人為的に切 り出し, 局所的な解析を目的としているものが多い (Qian et al., 2017, Kaneshiro et al., 2016, Koley and Dey, 2013）。本提案では, SAS 音声の特徵から, 解析対象部分を自動的に抽出し, 多変量解析により, 大域的な解析 と判別を行う. また, 従来の医療機関で行うSAS の診断は, 測定された $6 \sim 8$ 時間分の複数のデータを, 睡眠療法 土が手動で解析をし，その結果をもとに医師が診断をする．そのため, 被験者一人の診断に何時間も要する難点 がある. 本提案で必要なデータ時間は $1.5 \sim 2$ 時間程度, 解析時間も 20 分程度であり, 各過程の労力が大幅に削減 される.そして, 解析は自動で行われるため, 結果が一様となる. さらに, 本提案の結果は, グラフや表を用い て視覚的に提示するため, 被験者が理解と実感, 状況把握をしやすいという特徵がある. 本提案により, 国民の健 康意識向上への貢献が期待される.

次にこの論文の構成について述べる. 第 2 章では, 被験者データとその構成, SAS の音声波形の特徴, 本提案 の概要について述べる. 第 3 章では, 無音状態のヒストグラム作成の手順とその定量評価について, 第 4 章では, 睡眠中の呼吸音圧をもとにしたパターン分析について述べる. そして第 6 章では, 本提案の総合評価, および本 稿のまとめをする.

\section{2. 被験者データの構成と SAS の音声波形の特徵}

\section{$2 \cdot 1$ 被験者データとその構成}

先述のとおり，現行の SAS 診断では，睡眠中の呼吸音を用いない。しかし，SAS 罹患者の睡眠中の呼吸音には, いくつかの特徴があり（高橋, 1993），それらから SAS の疑いを指摘されるケースも多い（内田, 2013）。そこ で, SAS 罹患者の睡眠中の音声の特徵と傾向を解析するため, 豊橋メイツ睡眠治療クリニックょり, 1 泊入院によ る終夜睡眠ポリグラフ一検査における, 被験者の音声データと診断報告書の提供を受けた。これら被験者データ の内訳を次の表 1 に示す. なお, 本稿の被験者は豊橋技術科学大学の「人を対象とする研究規定」に基づく実験 計画審査を経て，十分な説明の後，インフォームドコンセントを得て実施した.

Table 1 Variable table of subjects.

\begin{tabular}{|c|c|c|}
\hline- & AHI & No. of people \\
\hline \hline Non SAS $^{*}$ & $(5<\mathrm{AHI})$ & 4 \\
Pre-SAS $^{*}$ & $(5<\mathrm{AHI})$ & 1 \\
Mild & $5 \leq \mathrm{AHI}<15$ & 5 \\
Moderate & $15 \leq \mathrm{AHI}<30$ & 11 \\
Severe & $30 \leq$ AHI & 21 \\
\hline- & Total $^{*}$ & 42 \\
\hline
\end{tabular}

表 1 の AHI 值はWHO（世界保健機関）により定められた無呼吸低呼吸指数（Apnea Hypopnea Index）であり, SAS の症状の重さを判断するための指数である（内田，2003）。ただし，これらの被験者データには，将来 SASになる 可能性が高い者, そして, 健康かつ将来 SAS になる可能性はない者がなかった．そこで, 上記クリニックとは別 に, 睡眠中の音声を収集し, 専門家の診断を経て採用をした。以後, 本稿では前者を SAS 予備群, 後者を非 SAS 
Shirasuna, Zhang, Toda, Ishikawa, Sakaguchi and Akiduki,

Transactions of the JSME (in Japanese), Vol.84, No.868 (2018)

者と呼ぶ。また, 後者は健康診断で異常がなく, 蓄膿症, アテノイド, 扁桃腺手術などの呼吸器官病歷がない者と 確認した。なお，本被験者の音声録音機器は，オリンパス社製，リニア PCMレコーダ LS-100 を用いる. 録音は 被験者の枕から約 $20 \mathrm{~cm}$ の距離, 鼻およびロから約 $25 \mathrm{~cm}$ の距離, そして自動利得制御機能が作動している条件の もとで行った。

ここで, 本稿が医工学的に解析を進めるにあたり，いくつかの留意点を述べる．まず，SAS の定義は WHO に 従い，一晚（7 時間）の睡眠中に 10 秒以上の無呼吸が 30 回以上，あるいは睡眠 1 時間あたりの無呼吸数や低呼吸 数が 5 回以上の場合の者を SAS 罹患者とする（佐藤，2016）。この無呼吸とは, 喉または鼻からの気流の停止と 定義されるが，睡眠中の音声データからはこれの判断が不可能であるため, 本稿では, 呼吸と呼吸の間隔の無音 状態区間が 10 秒未満であるものを無音状態，10 以上であるものを無呼吸と定義する. 次に，医学的には，いびき 症と SAS は区別される．前者には無呼吸や酸素の減少がみられず，単にいびき音だけがみられる症状を指す（佐 藤，2016）。本稿では，いびき音の規則性により，いびき症とSAS を区別できるため，いびき症は判別の対象と せず，SAS のみを対象する．よって，他の先行研究（高橋，1993）に倣い，本稿で扱う全ての音声データを睡眠中 の（異常）呼吸音と表記する。 また SASには, 閉塞性睡眠時無呼吸症候群（上気道の閉塞によるもので呼吸運動 はある), 中枢性睡眠時無呼吸症候群（脳の呼吸中枢の障害により呼吸運動が消失するもの）の 2 種類があり, こ れらが混合したものを混合性睡眠時無呼吸症候群と呼ぶ（内田，2013）。本稿の SAS 罹患者は, 全員が閉塞性で ある. 次に, 今回の被験者の音声データは概ね $5.5 \sim 6.0$ 時間であり, 全ての時間を解析するのはデー夕量が膨大に なる．そのため，睡眠に陥っている傾向が高い，録音開始 2 時間後から終了 2 時間前を採用している．さらに，現 行の SAS 診断では，REM 睡眠（脳が活発に動いている浅い眠り）と NON-REM 睡眠（脳も身体も休んでいる深 い眠り）のタームを考慮する（内田，2013）が，本提案は音声のみによる診断を行うため，これらを考慮しない．

\subsection{SAS の音声波形の特徵}

SAS 罹患者と非 SAS 者について, 睡眠中の呼吸音を比較すると, 前者には以下の 3 つの大きな特徵がみられる. 特徵 1 ：無音状態は，呼吸リズムが乱れているときに起こりやすい。この例を図 1 に示す。ただし図の（a）は 呼吸リズムが一定の例で, (b) は呼吸リズムに乱れがある例である.

特徵 2 ：無音状態から呼吸再開時に大きな呼吸音が発せられることが多く，これに幾つかのパターンがみられ る.この例を図 2 に示す. 図の（a）は無音状態の後, 赤い矢印で示したような小さい呼吸が再開している. （b）は無音状態の後, 短いリズムで呼吸を再開している. (c) は無音状態の間に息継ぎのような呼吸がある.

特徵 3 ：呼吸音は比較的高音圧で, 声道（上気道）からの振動音を含む傾向がある. この例を図 3 に示す.

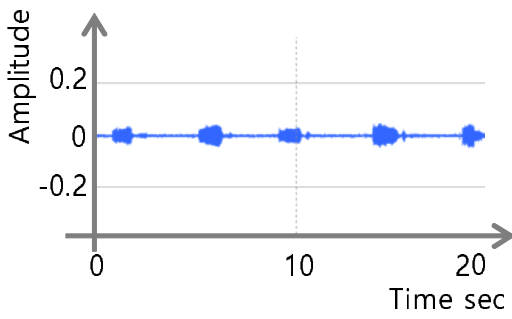

(a) Constant rhythm sleep breath sound

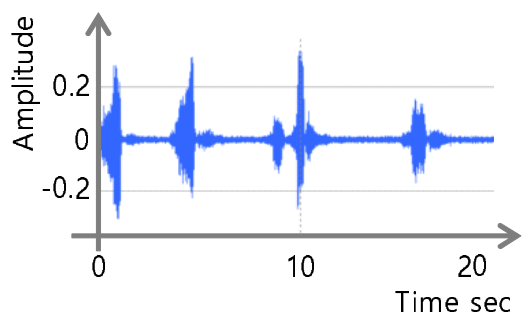

(b) Non-constant rhythm sleep breath sound

Fig. 1 Example of constant rhythm and non-constant sleep breath sound, where (a) shows Non-SAS sleep sound and (b) shows SAS sleep sound that is not constant than (a).

そこで, 本提案ではこれら 3 つの特徵 : 無音状態, 呼吸リズム, 高音圧に着目した, SAS 判別法および予備群 早期発見プロセスを提案をする.

\section{$2 \cdot 3$ 処理の流れと判別プロセス}

ここからは, 本提案の具体的な内容について説明する. 提案は以下の 5 段階処理および 3 段階判別からなる. 


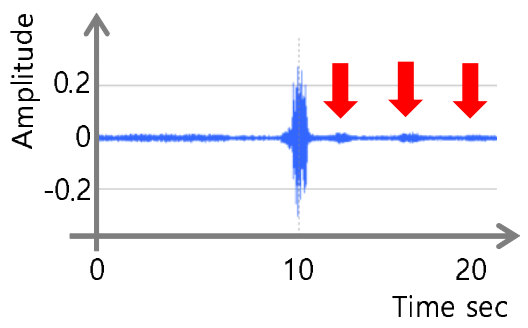

(a) Apnea and restart constant rhythm sleep breath sound

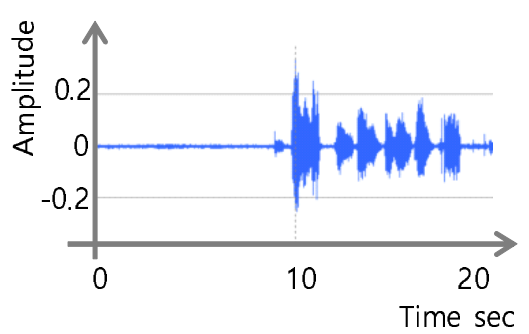

(b) Apnea and restart no-constant rhythm sleep breath sound

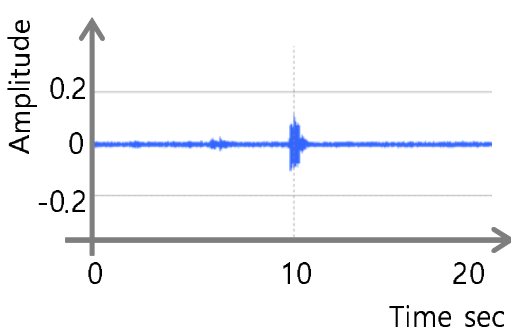

(c) Apnea and just one breath sleep breath sound

Fig. 2 Example of apnea and sleep breath sound, where (a) shows small breathing resumed after the silence condition, (b) shows respiration restarted with a short rhythm after the silent state, (c) shows breathing during the silent state.

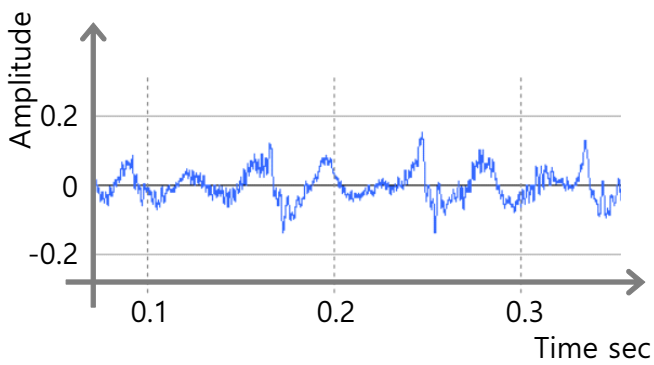

Fig. 3 Example of SAS waveform sound. The respiratory sound is relatively high sound pressure and tends to include vibration sound from the vocal tract (upper airway).

段階 1 ：睡眠中の音声の録音

ICレコーダで，睡眠中の呼吸音を 1.5 時間以上録音する.

段階 2 : 事前処理

段階 1 の音声データについて, 連続する 1.5 2 時間程度を抽出し，ノイズ除去とダウンサンプリングを行う.

段階 3 : 無呼吸・無音状態区間の秒数度数ヒストグラム作成

無音状態を秒数毎にカウントし，ヒストグラムを作成する.

段階 4 ：クラスタ分析による呼吸パターン傾向の把握

高音圧の呼吸音を中心とし，その前後の呼吸傾向をもとに，呼吸のパターンをクラスタリングする.

段階 5 ：段階 3 および 4 を併用した総合判別

段階 3 および 4 を併用し，SAS 予備群および罹患者の可能性を総合判別する.

上記の 5 段階のフローチャートを図 4 に示す. 解析を用いた判別は段階 3 および 4 であり, 段階 5 において, こ れらを併用した判別をする。ここでは，それらの事前処理となる段階 1 と 2 につい説明を行う.

まず，段階 1 の睡眠中の呼吸音は，簡易 ICレコーダにより録音する．録音時間は長時間であるほど望ましいが， 本提案では, 1.5 時間以上のデータで解析が可能であることを確認している. また，本稿ではサンプリングレート $44.1 \mathrm{KHz}$ で録音をしている.

次に, 段階 2 で, 段階 3 の前処理として, 簡易ノイズ除去とダウンサンプリングを行う. 前者については, 睡眠 中の呼吸音と暗騒音の区別についての報告はあるが（Nishijima et al., 2017），(数納他, 2013）, 本提案における 解析は両者の区別が目的ではないため, 概ねの暗騒音を除去できれば良いとする. なお，今回のサンプル中の最 大の暗騒音は $-40.0 \mathrm{~dB}$, 最小值は $-94.0 \mathrm{~dB}$ である. しかしながら，この数值は録音環境により異なるこため，暗 騒音の設定は，録音環境に応じた設定が必要になる．さらに，録音した音声データを $16.0 \mathrm{kHz}$ にダウンサンプリ ングして解析を行う.いびき音の周波数解析においては，これより低いものでも解析が可能であるが (Kim et al., 2017)，(Shiomi et al., 2011)，本提案は非 SAS 者も対象としていること，さらには計算に時間を必要としない方 
Shirasuna, Zhang, Toda, Ishikawa, Sakaguchi and Akiduki,

Transactions of the JSME (in Japanese), Vol.84, No.868 (2018)

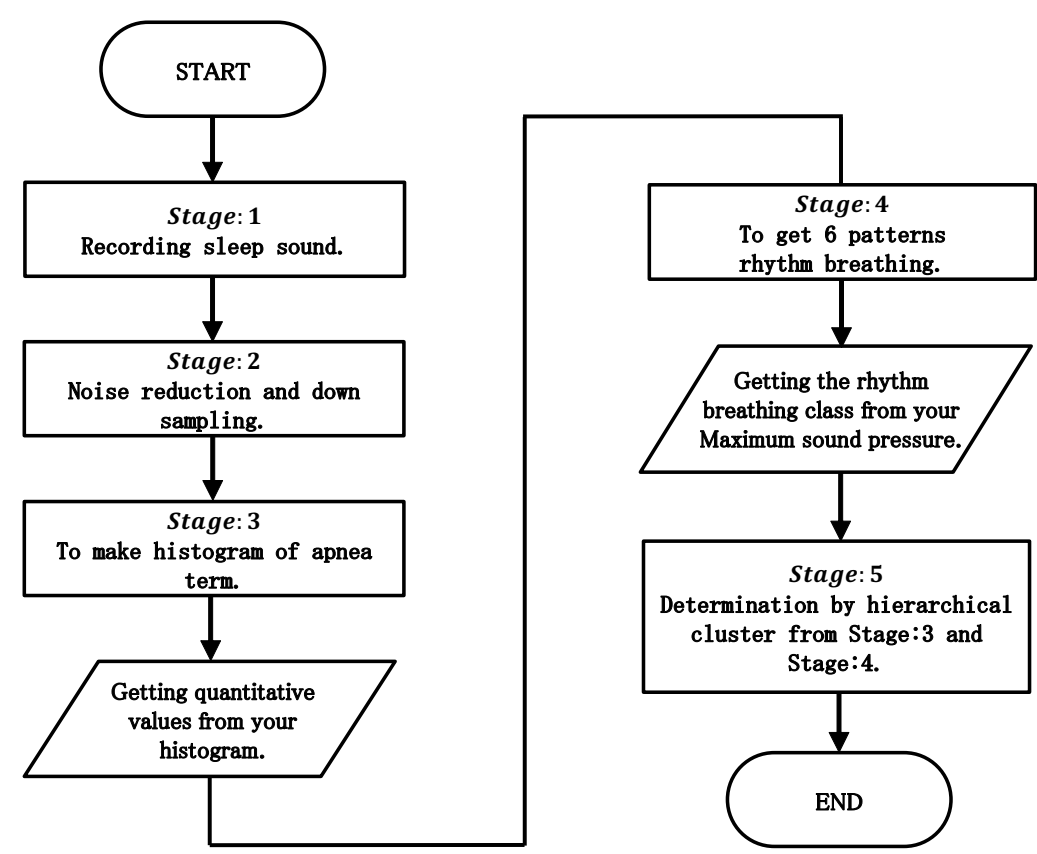

Fig. 4 Flowchart of SAS diagnosis, where steps 1 to 3 are preparation for analysis, and analysis is performed in steps 4 and 5 .

法を用いているため，人間の音声の周波数特性を考慮し，今回はこのサンプリングレートで実行している.

\section{3. 無呼吸・無音回数区間状態のヒストグラム作成と定量評価}

\section{$3 \cdot 1$ 呼吸状態の把握}

本提案の段階 3 の無呼吸回数のヒストグラム作成について述べる.これは, 前章で SAS 音声の特徵として挙げ た，無音状態に着目したものである.

SAS 罹患者の呼吸音で最も顕著な特徵は，呼吸音の停止である．医療機関でSAS の診断を受けた者は，検査診 断結果として，1 時間あたりの平均呼吸停止回数，および一晚の呼吸停止総回数を数字で提示される. しかしなが ら, これらはSAS の定義を満たしたものがカウントの対象となる. 本提案では, 定義に満たない呼吸停止秒数も カウントし, 無呼吸・無音状態区間の秒数度数を視覚化する.これにより, 隠れ SAS および予備群の発見にも繋 がる．以下に，無音状態区間の秒数度数をカウントするための手順を示す.

段階 3.1：呼吸有無の二值化

まず，段階 2 で残留したノイズを除く.ここで，音声データの呼吸と呼吸の間，つまり無呼吸・無音状態の区 間を呼吸間と定義する。そして，この呼吸間をランダムに 5 か所選び，その最大音圧を閾值と設定し，これよ り高い音圧を呼吸有り，それ以下を呼吸無しとみなし，呼吸音を二值化する。この例を図 6 に示す．図中の 矢印の区間が一定時間以上のときに無音状態区間とみなす。ここでは， 0.5 秒以上としている．閾值を $p>0$ とし，時刻：t>0における呼吸有り：1, 無し：0 とすると，式(1)のようになる.

$$
B\left(t_{i}\right)= \begin{cases}1 & \left(\max |\mathrm{dB}| \text { in }\left[t_{i-1}, t_{i}\right) \geq p\right) \\ 0 & (\text { otherwise })\end{cases}
$$

ただし， $i=1,2, \ldots, n$. なお，今回は $t_{i}$ を 0.25 秒刻みで算出し，小数点以下を四捨五入している.

段階 3.2 : 無呼吸・無音状態区間の秒数のカウント

式 (1) において $B\left(t_{i}\right)=0$ となる連続時間区間をカウントし，無呼吸・無音時間区間の回数/時間のヒストグラ ムを作成する。このフローチャートを図 7 に示す。二值化された值が 0 である，無呼吸・無音状態の合計秒 数を求め, その各值について, 時間内の度数をカウントする. 


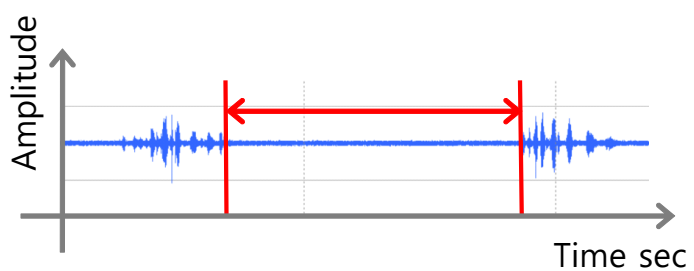

Fig. 5 Example of no sound interval, where silent state between breathing sounds is set as apnea or silence section.

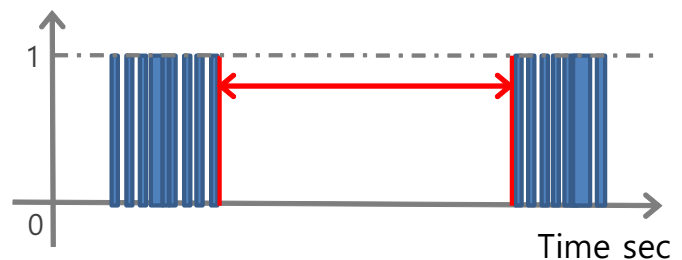

Fig. 6 Example of no sound and breath binarization. Binarize the presence or absence of sound, and calculate the number of seconds for section of apnea or silence.

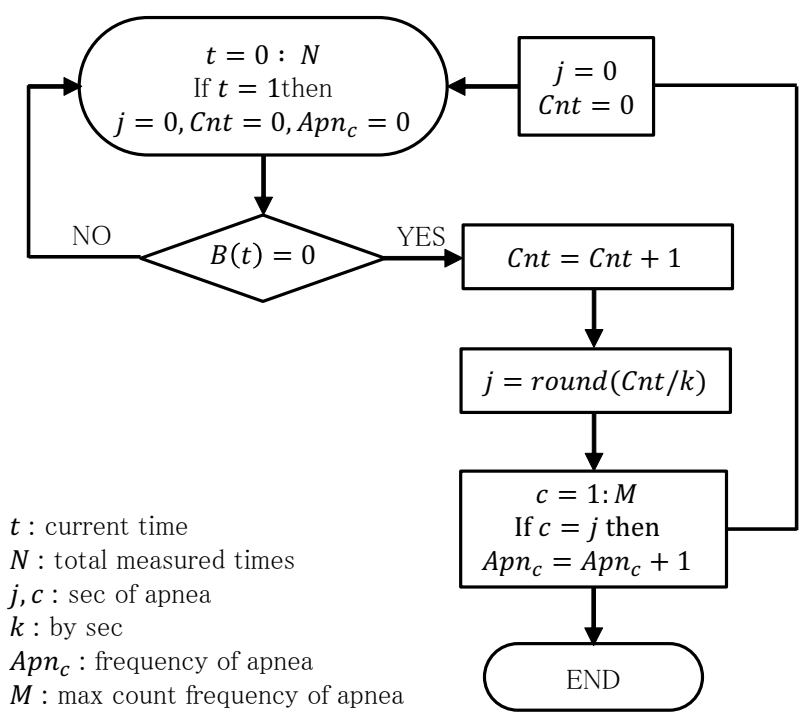

Fig. 7 Flowchart of making no sound histogram.

\section{$3 \cdot 2$ 無呼吸・無音状態区間の秒数度数ヒストグラム作成}

段階 3.1 から 3.2 を経て無音状態区間の秒数度数ヒストグラムを作成した例を図 8 に示す。この例は, 非 SAS 者 と中等度の SAS 罹患者について，16.0 kHz，録音時間 $1.5 \mathrm{~h}$ を 1 時間あたりに換算して作成している。図の縦軸は 度数，横軸は無呼吸・無音区間の秒数を表し，白抜きの棒グラフは非 SAS 者，オレンジ色の棒グラフは中等度の SAS 罹患者を表す.

この結果を被験者の診断報告書と比較してみる。診断報告書は総睡眠時間における無呼吸回数をカウントしてい るが，本提案は $1.5 〜 2$ 時間の音声データを用いている.これを調整するため, 診断報告書と被験者毎の音声デー タについて，1 時間あたりの無呼吸回数に換算して比較をした。この結果を図 9 に示す. 図の横軸は 1 時間あたり の診断報告書の無呼吸回数, 縦軸は音声データから算出した 1 時間あたりの無呼吸回数である. また，図中の白 抜きの丸は軽度, 三角は中等度, 中塗りの丸は重度の罹患者である.なお，診断報告書はクリニックで診断を受 けていない非 SAS 者, SAS 予備群については, この図に含まれず，10 秒未満の無音状態については，診断報告書 に含まれない. 結果として, SAS の定義である 10 秒以上の無呼吸回数において，平均 $2.6 \%$, 最大で $8.0 \%$ の誤 差があり，相関係数は 0.94 である. これより，診断報告書の回数より本提案の方が，やや無呼吸回数を多く算出 していることがわかるものの，比較的良好な結果が得られている. 誤差の具体的な原因として，本提案は，1.5～ 2 時間のデータを切り出しているため, 医療機関の検査結果に必要な 8 時間の結果とは誤差が生じていることが考 
Shirasuna, Zhang, Toda, Ishikawa, Sakaguchi and Akiduki,

Transactions of the JSME (in Japanese), Vol.84, No.868 (2018)

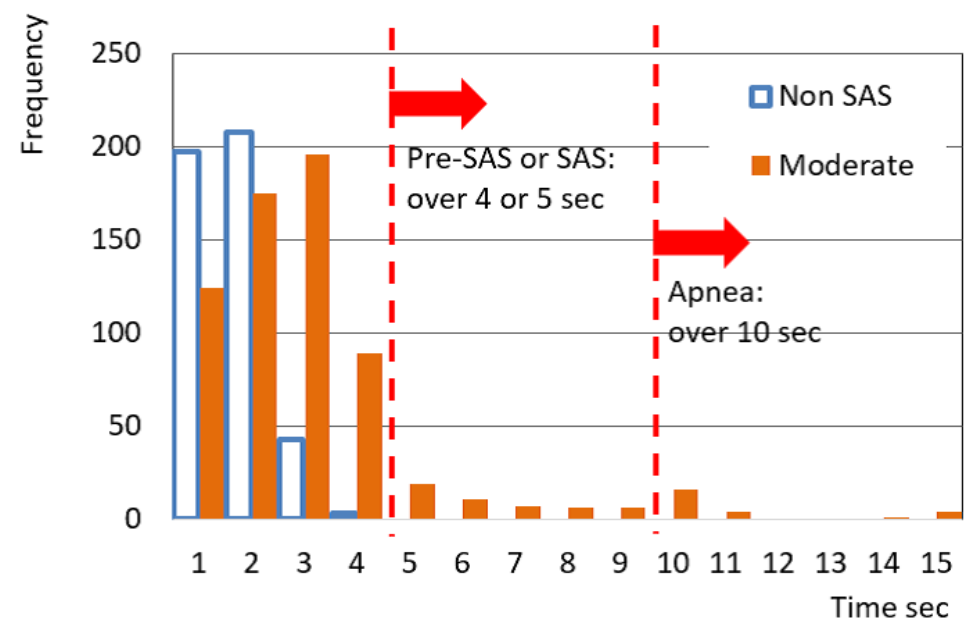

Fig. 8 Example of no sound interval histogram, non SAS and moderate. A histogram is prepared for the number of apnea or silence states per hour. By comparing histogram between Non-SAS person and moderate SAS person, we can know that the silence state of the Non-SAS person is less than four seconds and moderate SAS people are in long tail state.

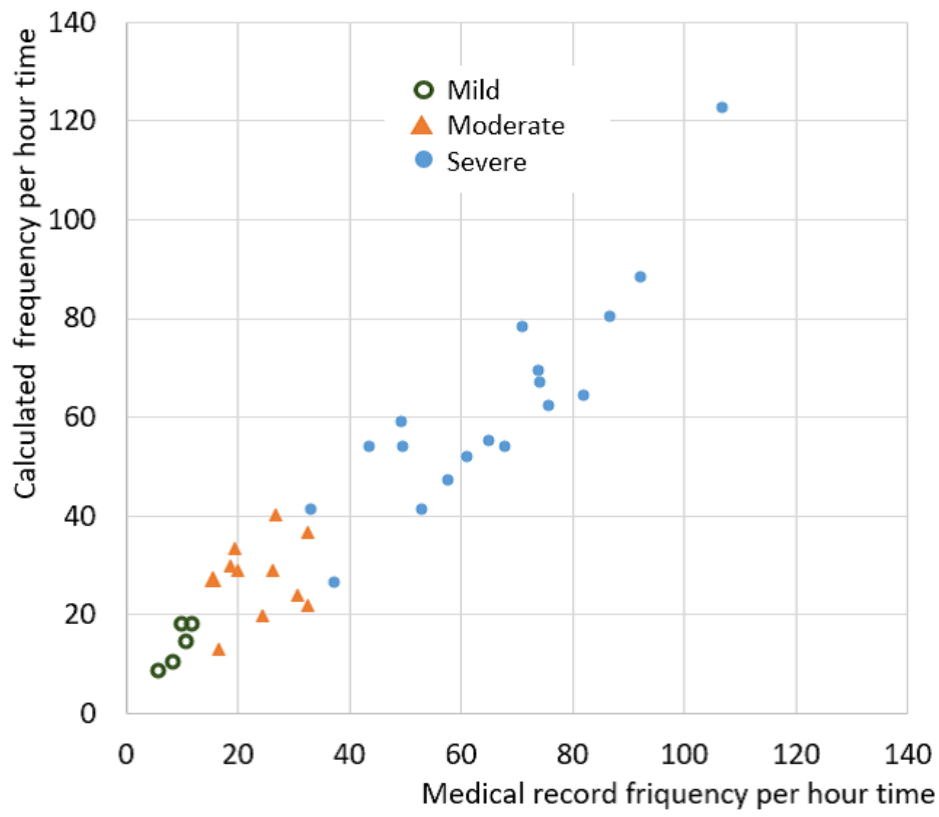

Fig. 9 Regarding the number of apnea states per hour, we compare this proposal with the medical records, but comparing no sound interval medical record with calculated time. Although this proposal is somewhat more frequent than charts, good results are obtained. Since Non-SAS persons and Pre-SAS persons do not have charts, they are not compared.

えられる. また, 音声データのみを用いているため, 騒音を呼吸音とみなされていること, 音声が暗騒音以上で あっても，無呼吸と判断されてしまうことがあげられる．さらには，録音音量の設定も要因のひとつであり，これ については今後の課題としたい.

\section{$3 \cdot 3$ ヒストグラムによる SAS の可能性定量評価}

本提案では，前節で作成したヒストグラムをもとに SAS の傾向を定量的に評価する. 例えば，図 8 に示される ように，非 SAS 者においては，0 秒以上〜4 秒未満の無音状態区間が度数の約 $99 \%$ 以上が集中する傾向がみられ る. これは, 健康者の覚醒時の平均呼吸数は 12〜20 回/分, つまり, ひと呼吸 : 4 5 秒であり, 睡眠時はこれよ り若干緩やかだが，覚醒時とほぼ同じである報告と一致する（玉置，2013）。すなわち，吸って吐く動作が 4〜5 
秒に繰り返され，睡眠中はこれよりやや緩やかな周期となるため，無音状態が 1〜3 秒前後に集中する. このため, 非 SAS 者のヒストグラムは，無音状態区間が 0 秒以上〜3 秒未満についてのみ度数が現れる，一方で，SAS 予備 群および罹患者については，例えば，図 8 の左側の矢印で示したように，4秒以上にも度数が出現し，ロングテー ル状態になる.

そこで, 非 SAS 者, SAS 予備群および罹患者について, ヒストグラムの標準偏差, 丕度, 尖度を求めた。この 結果を図 10 に示す．縦軸は算出値, 横軸は右から標準偏差, 歪度, 尖度を示す.また, 横軸の各カテゴリ内は, 左から順に非 SAS 者, SAS 予備群, 軽度, 中等度, 重度の SAS 罹患者であり，それぞれの縦線は，それぞれの下 段 : 最小值, 中段 : 平均值, 上段 : 最大值を示す.

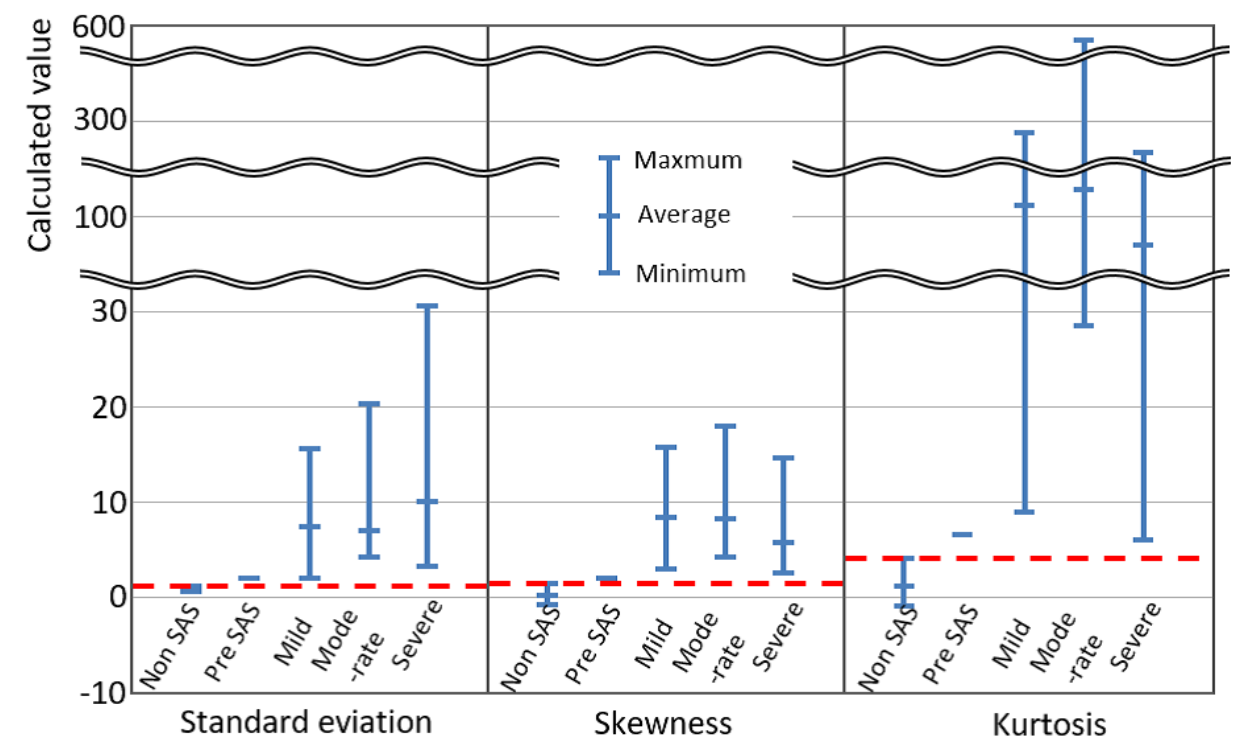

Fig. 10 Values of standard deviation, skewness and kurtosis from histogram. For the created histogram, the standard deviation, skewness, and skewness of Non-SAS, Pre-SAS and SAS were calculated. Furthermore, the maximum value, minimum value, and average value are shown in figure. The maximum value of standard deviation, skewness, skewness of Non-SAS is smaller than the minimum value of Pre-SAS and SAS.

本提案の目的は, SAS の可能性判別とその予備群の早期発見であるため, 非 SAS 者, SAS 予備群および罹患者 について, 標準偏差, 歪度, 尖度の各值を比較し，その違いをみる。図 10 の標準偏差, 歪度, 尖度における赤い 破線は，非 SAS 者について各值の最大值を示す．この結果から，SAS 予備群以上の各最小値は，非 SAS 者の最大 值よりも大きいことがわかる. つまり, 非 SAS 者の各最大值と, 予備群を含めた SAS 罹患者の最小值で二分が可 能であると示唆される。そこで, 全被験者について, これら標準偏差, 歪度, 尖度の各值を説明変数, 非 SAS 者 と SAS 予備群および罹患者の情報を従属変数とし，判別分析（青木，2009，永田，棟近，2001）を行ったそその 結果を図 11 に示す.

図 11 の白抜きの棒グラフは非 SAS 者, 中塗りは予備群を含む SAS 罹患者であり, 縦軸は前者，あるいは後者 全体に対する百分率を示し，横軸は判別に用いた判別值である．赤い破線が判別の境界であり，右側に全ての非 SAS 者が分類されている．そして，この赤い破線の右側に近い判別值が 1 に属する被験者 2 名は, SAS 予備群お よび中等度の罹患者であり，誤判別されている．結果として，判別分析の正解率は，95.2\%である．誤判別となっ た SAS 予備群について，ヒストグラムを確認すると，非 SAS 者の形状と同様に，横軸である無音秒数が 2 秒に最 頻度を取り，そして，その形状の左側にロングテールが不随されているような形状になっている．これにより，誤 判別になったと考えられる. また，中等度の 1 名について音声データを確認したところ, 無呼吸状態を確認でき るものの, 終夜を通じて比較的同じ周期で 15 秒未満の無呼吸状態と安定した呼吸を繰り返している. このためヒ ストグラムが安定した形になり，誤判別になったと考えられる. 
Shirasuna, Zhang, Toda, Ishikawa, Sakaguchi and Akiduki,

Transactions of the JSME (in Japanese), Vol.84, No.868 (2018)

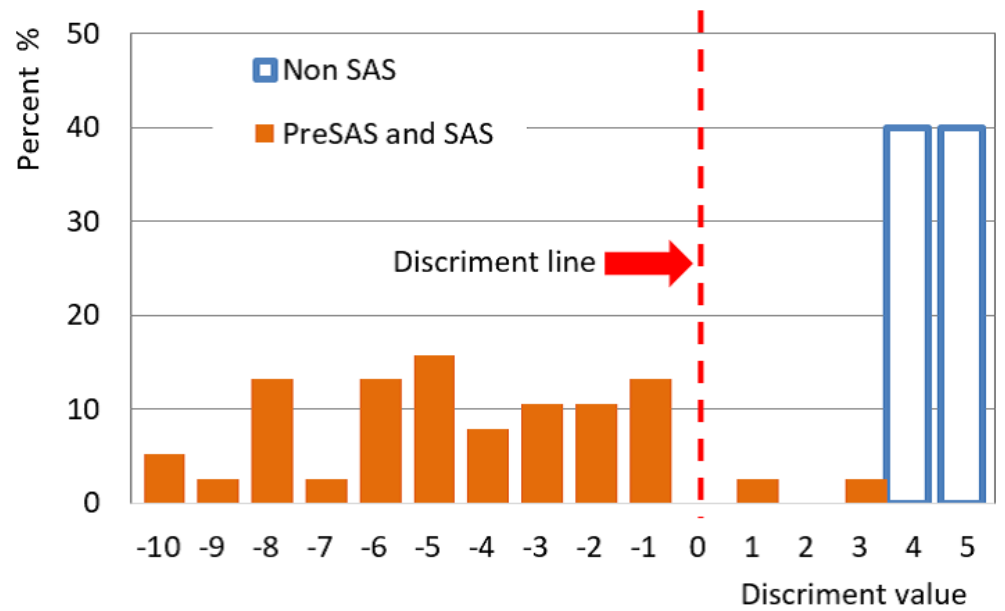

Fig. 11 Discriminant analysis from histogram. Discrimination analysis was carried out with each value of standard deviation, skewness, and kurtosis as explanatory variable, information on non-SAS person and SAS preliminary group and affected subject as dependent variable. White bar graphs are non-SAS persons, brown bars is SAS sufferers including preliminary group, the vertical axis shows $\%$ of the former or the latter, and the horizontal axis is the discrimination value used for discrimination. The red dashed line is the boundary of discrimination, and all the non-SAS persons are classified on the right side. Two subjects whose discrimination value close to the right side of the red dashed line belongs to category one are the SAS preliminary group and the moderately affected person and are erroneously discriminated. The accuracy rate of discriminant analysis is $95.2 \%$.

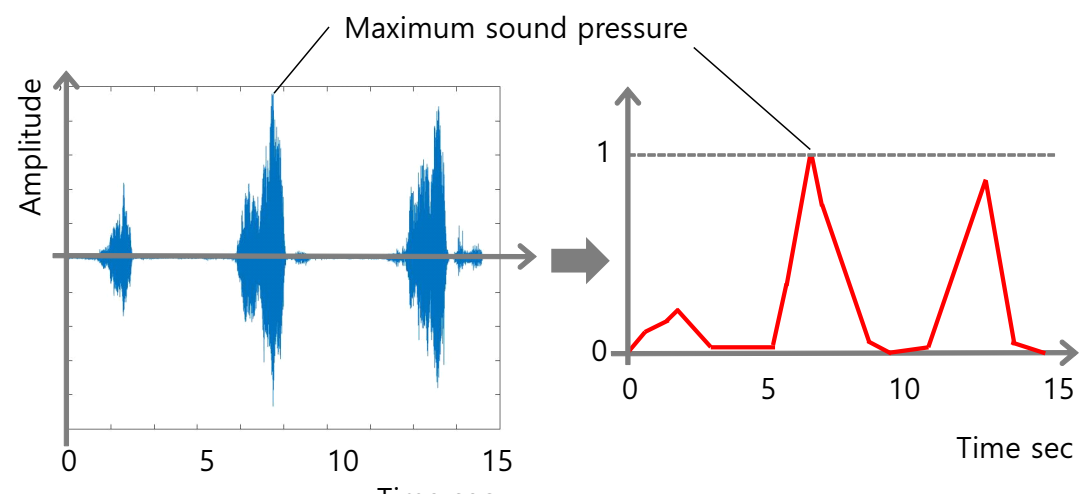

(a) Extract of $15 \mathrm{sec}$ sound

(b) Normalization

Fig. 12 Pulled out sound and normalization, where (a) is example of pulled out 15 seconds sound that is centered maximum sound pressure, (b) is example of normalized (a).

\section{4. クラスタ分析による呼吸パターン傾向の把握}

この章では，段階 4 について説明をする。これはSAS の呼吸音の特徵である，無音状態，呼吸リズムおよび高 音圧に着目したものである.

被験者データの音声を確認すると，無音状態からの呼吸再開時において，高音圧な呼吸音が発せられる傾向が みられる。そこで，被験者データから，この呼吸再開時のパターンを統計的に解析したところ，概ね 6 種類のク ラスに分類されることがわかった．解析は次のような手順で行った.

段階 4.1 : 呼吸の抽出

各被験者データについて，録音時間内の呼吸音の絶対值の最大音圧上位 5 個を検索し，その最大值を中心に 前後 7 秒（最大值を含め 15 秒）を抽出する.このとき，互いの音声には 3 分以内の重複がないものとする. なお，抽出する最大音圧がパルス信号のように突出してるものを対象外とするため，検索されたデータにつ

いて，包絡線を描きその形状から判断をした。

段階 4.2 : 音声正規化

段階 4.1 で切出した各音声データについて絶対值を求め, 中央の最大音圧を基準に正規化をする. 

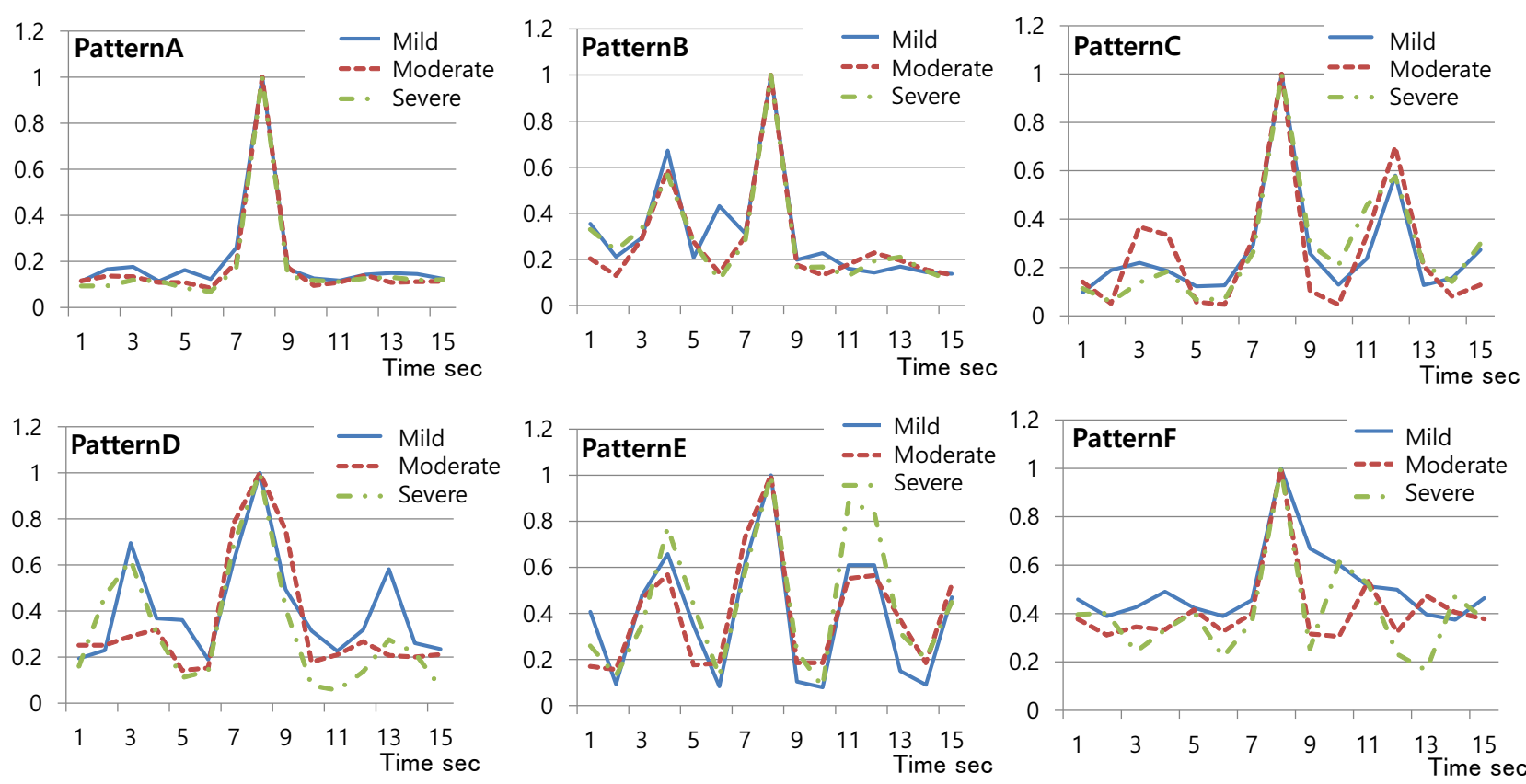

Fig. 13 Classter 6 patterns sleeping breathing rhythm. A maximum sound pressure was first selected, and then 5 seconds were cut out before and after the sound pressure for each subject and clustering was performed with k-means. Six breathing patterns were obtained. Patterns A and B are outstanding patterns of SAS.

段階 4.3 : クラスタリング

段階 4.2 で正規化された各被験者の 5 個のデータをもとに，SAS の症状の重さとは無関係に k-means 法でク ラスタリングする.

上記の手順を施し, 段階 4.3 の k-means 法（井出，2015，永田，棟近，2001，MacQueen，1967）でクラスタリン グしたパターンと SAS の症状の重さ（健康に問題ない者から重症の SAS 罹患者まで）の内訳を表 2 に，そのパ ターンの概形を図 13 に示す. 表 2 については, 各被験者の 5 個のデータが重複してクラスタリングされているも のもあるため，その重複を除いた人数で示した．なお，各分母は各 SAS の症状の重さの総被験者数とする. 表 2 の太字は，SAS 罹患者の各進行度において約 40\%以上出現したものを表す。また，図 13 は SAS 罹患者のみを表 示する.

Table 2 The detail of samples of six patterns sleeping breathing rhythm.

\begin{tabular}{|c||c|c|c|c|c||c|}
\hline & Non SAS & Pre-SAS & Mild & Moderate & Severe & $\begin{array}{c}\text { The proportion in } \\
\text { relation to SAS* }\end{array}$ \\
\hline \hline PatternA & $0 / 4$ & $0 / 1$ & $2 / 5$ & $\mathbf{1 1 / 1 1}$ & $\mathbf{1 9 / 2 1}$ & $86.5 \%$ \\
PatternB & $0 / 4$ & $\mathbf{1 / 1}$ & $\mathbf{4 / 5}$ & $\mathbf{9 / 1 1}$ & $\mathbf{8 / 2 1}$ & $56.8 \%$ \\
PatternC & $0 / 4$ & $\mathbf{1 / 1}$ & $\mathbf{4 / 5}$ & $3 / 11$ & $\mathbf{8} / \mathbf{2 1}$ & $40.5 \%$ \\
PatternD & $0 / 4$ & $0 / 1$ & $2 / 5$ & $3 / 11$ & $4 / 21$ & $24.3 \%$ \\
PatternE & $\mathbf{4 / 4}$ & $\mathbf{1 / 1}$ & $1 / 5$ & $2 / 11$ & $5 / 21$ & $21.6 \%$ \\
PatternF & $0 / 4$ & $0 / 1$ & $\mathbf{3 / 5}$ & $1 / 11$ & $2 / 21$ & $16.2 \%$ \\
\hline
\end{tabular}

unit : people, $^{*}$ : Mild, Moderate and Severe

図 13 と表 2 を合わせて考察すると, SAS 罹患者において次のような傾向がみられる.

パターン A : 無音状態中に息継ぎのような呼吸を 1 回. 中等度から重度の $90 \%$ 以上の確率で出現.

パターン B : 小さな呼吸の後, 大きく呼吸し, 無音状態へ. 軽度から中等度の約 80 90\%の確率で出現.

パターン C : 無音状態に近い後, 大きい呼吸とともに呼吸再開. 軽度の $80 \%$ の確率で出現. 
Shirasuna, Zhang, Toda, Ishikawa, Sakaguchi and Akiduki,

Transactions of the JSME (in Japanese), Vol.84, No.868 (2018)

パターンD：呼吸リズムと量が乱れた中で, 大きな呼吸を 2〜3 回. 軽度から重度の $25 \%$ 弱の確率で出現.

パターンE：一定の呼吸リズムの途中に, やや大きな呼吸. 重度の $25 \%$ 弱の確率で出現.

パターンF：呼吸リズムが乱れた小さな呼吸の最中に大きな呼吸音. 軽度の $60 \%$ の確率で出現.

パターン A は，SAS 罹患者の $86.5 \%$ に該当する．また，SAS の特徵である無音状態からの呼吸再開はパターン $\mathrm{C}, \mathrm{D}, \mathrm{F}$ である. なお, 各被験者で同一パターンの重複がある者について傾向をみたところ, 重度の罹患者にパ ターン A の重複が多くなっている．これは，無呼吸が常習化しているためと考えられる.

本提案の目的である SAS 予備群の早期発見の対象に最も近い, 軽度の罹患者に着目すると, パターン $\mathrm{B}$ と C が みられる. よって, パターン B と C が, SAS の予兆にもみられる可能性がある.

そこで, 軽度と重度の 2 グループのみについて, 二值の判別分析（青木, 2009, 永田, 棟近, 2001）を行った. パターン $\mathrm{A}, \mathrm{B}, \mathrm{C}$ を説明変数, 軽度あるいは重度を従属変数をとしたところ, 正解率 $88.46 \%$ の判別結果が得ら れた。誤判別となった者は, 軽度の 5 人中 1 人で, パターン $\mathrm{A}$ と $\mathrm{C}$ のを有する者. 重度では 21 人中 2 人で, パ ターン A， B およびC のすべてを有する者である。この結果より，SAS 初期状態においては，パターン B および $\mathrm{C}$ がみられ, 進行にともない, パターン A の出現が増す傾向があると考えらえる. また, 今回の非 SAS 者は全て パターン Eに分類される．ただし, SAS 罹患者とは異なり, 中心の最大音圧とその前後の呼吸の音圧の比は, 最 大音圧を 1 としたとき，0.82〜0.94であり，3つの山の高低差は小さい. これより, 非 SAS 者の呼吸音および呼 吸の間隔は, 比較的安定していることがわかる.

\section{SAS の判別とその予備群発見のための総合判別と提案}

\subsection{SAS の判別とその予備群発見のための総合判別}

本章では, 前章までの結果をもとに, SAS の判別とその予備群発見のための総合判別と提案を行う.

第 3 章では, 無音状態のヒストグラムを作成し, その形状について判別分析（青木, 2009, 永田, 棟近, 2001） を行った．現在のサンプルからは, SAS 予備群の可能性を示すための明確な間值は設定できない. しかしながら, 作成したヒストグラムによると, 今回のサンプルからは 4 秒以上の無音状態, あるいは, 適宜に設定する SAS の 定義である 10 秒以上の呼吸停止よりも短い秒数の無音状態が確認されれば, SAS 予備群および SAS の可能性が 疑われることが解った。 さらには, ヒストグラムをもとに標準偏差, 歪度, 尖度を算出し, 判別分析を用いること により, 定量的な SAS 予備群の可能性, およびSAS の良好な判別が行えることが示された。しかしながら, SAS 予備群および罹患者でありながら, 非 SAS 者に誤判別されてしまう可能性がある.

第 4 章では, 各被験者について最大音圧前後の 15 秒の呼吸音を 5 個ずつ抽出し，それらをもとにクラスタ分析 を行った。これにより, 呼吸パターンは 6 種類のクラスに分類され, SAS 予備群および罹患者の呼吸パターンに ついて，3つのパターンが確認された。しかしながら, 非 SAS 者, 予備群および罹患者に共通で出現するパター ンも確認され，これらの判別を明確にする必要がある.

そこで, これらの問題を考慮し, 第 3 章と第 4 章の解析および結果をもとに, 2 つの解析を併用した SAS の判別 とその予備群発見のための総合判別として, 階層型クラスタ分析 (井出, 2015, 青木, 2009, 永田, 棟近, 2001) を行う. 全被験者について, 第 3 章のヒストグラムから算出した標準偏差, 歪度, 尖度, そして第 4 章の 6 種類 のクラスタについて, クラスタ間の距離に WPGMA 法, 距離計算に Correlation を用いて，2つのクラスヘ分類を した。この結果を図 14 に示す.

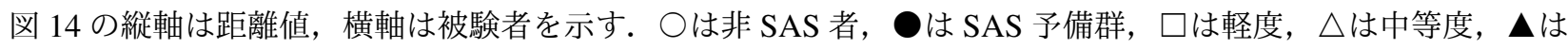
重度の罹患者である. 右上方の赤い破線は，2 階層に分類されるラインであり，右側の非 SAS 者と左側の予備群 および罹患者に分類されている. よって, 段階 3 において誤判別された 2 名については, 正しく分類されている.

次に, この階層型クラスタ分析の有用性について検証を行った. 今回は被験者数が 42 名と少ないため, leaveone-out 交差検証（井出，2015，C.M. ビショップ，2008）を用いた. 結果として，42 回の検証において，誤分類は 見られなかった.SAS 予備群および罹患者を非 SAS 者と分類されないことが，本提案の最重要であるため, 段階 3 および段階 4 の解析を併用により, 誤判別の軽減および回避が可能であると示された。本稿の被験者データにお いては誤判別はないが, サンプル数が少ないため, 今後サンプル数を増やし, 提案手法の解析精度と信頼性の向 上を図りたい。 
Shirasuna, Zhang, Toda, Ishikawa, Sakaguchi and Akiduki,

Transactions of the JSME (in Japanese), Vol.84, No.868 (2018)

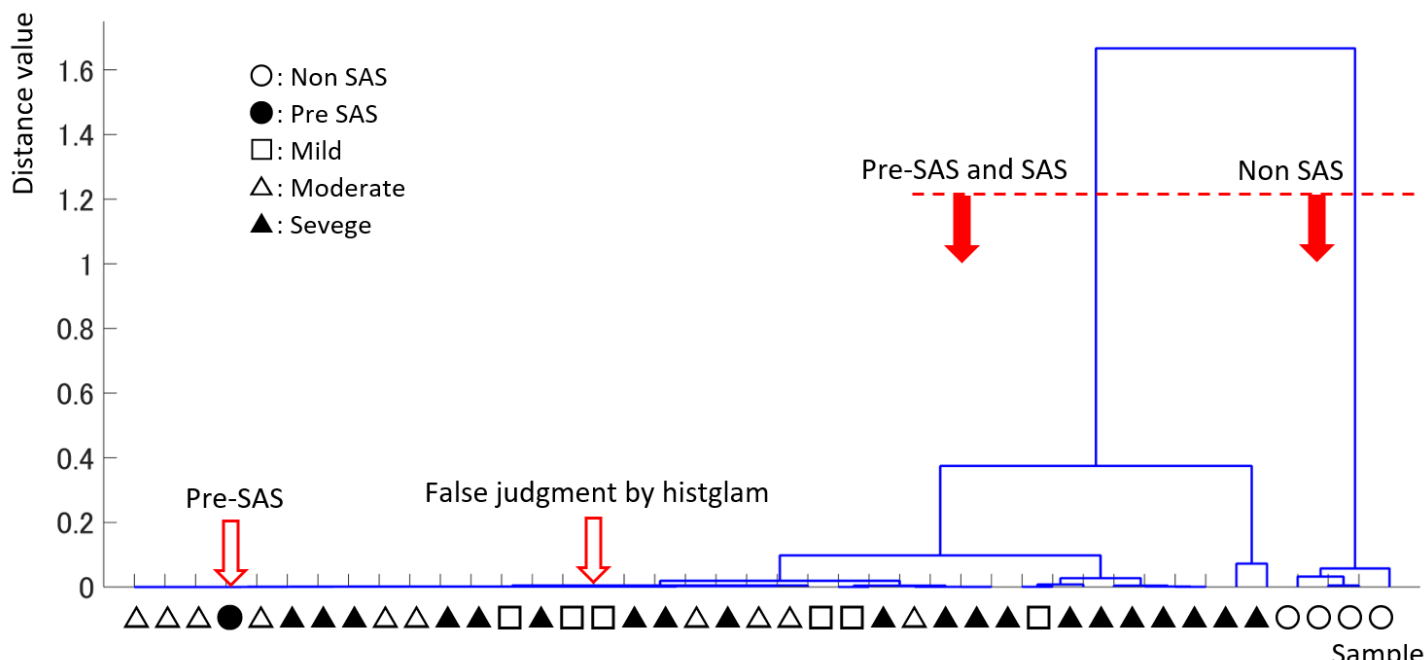

Fig. 14 Hierarchical clustering was performed to comprehensively judge the result of the discriminant analysis by the histogram of silence and apnea and the result of clustering by k-means. As the results, Non-SAS, Pre-SAS and SAS are distinguished. One of SAS who got misidentified by discriminant analysis based on the histogram of silence and apnea count is correctly discriminated.

\subsection{SAS の判別とその予備群発見のための提案例}

前節の結果をもとに，本提案を用いた SAS の判別とその予備群発見のための総合判別が可能となる. 例えば, 図 15 のように, 段階 3 および 4 の結果を 1 枚のシートに集約し, 被験者に提示する.このとき, 第 5.1 章で行っ た総合的な検証も行う。これにより, 被験者は SAS および予備群の可能性を知ると同時に, 睡眠に関する健康意 識を高められる.

また，この提示は，被験者の睡眠健康状態の推移比較も可能となる. 例えば, 無音状態が改善されれば, 各解 析結果にも反映される.これにより，被験者へ改善度合の明示，そして改善効果の視覚的な把握が期待される.

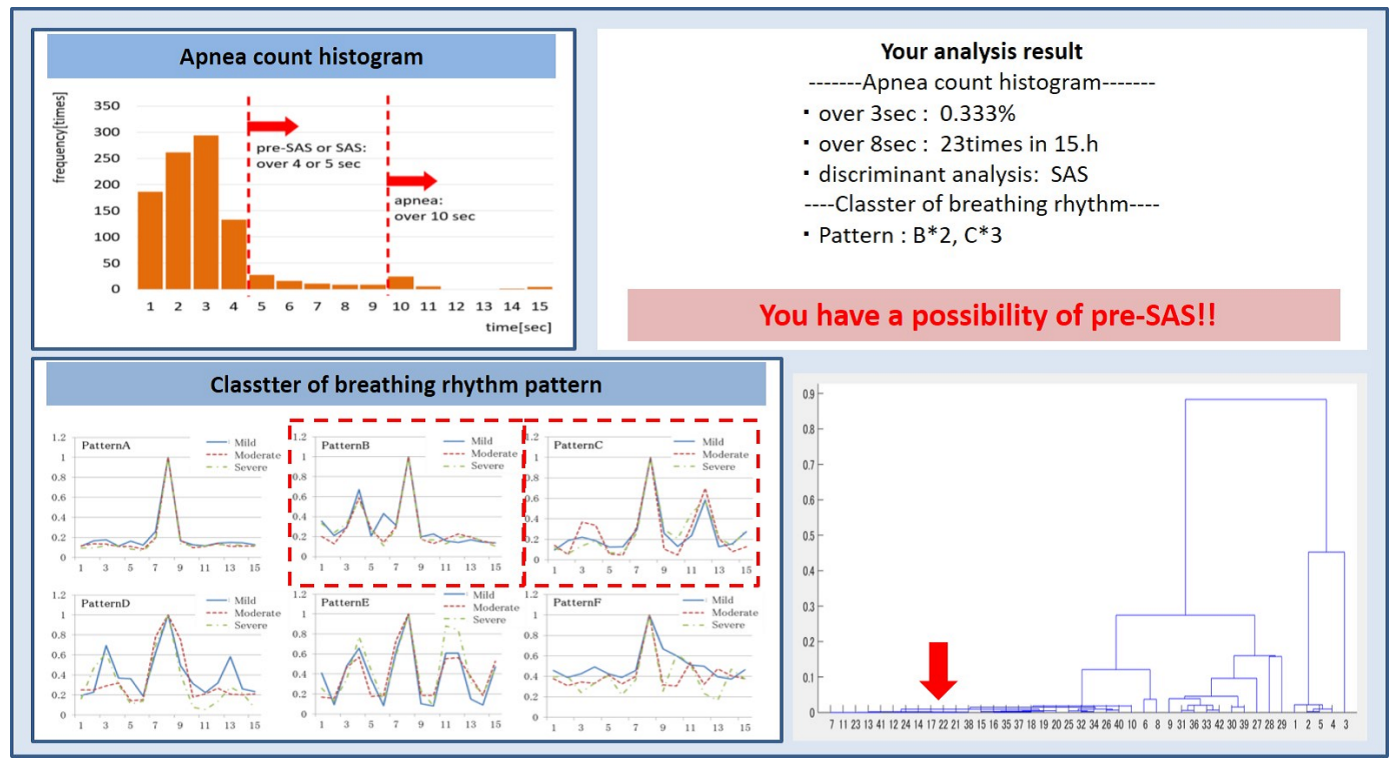

Fig. 15 Example of proposal for Sleep Apnea Syndrome discriminating method and discovery process pre-SAS. As in this example, we show the possibility of pre-SAS and SAS by performing clustering of silence and apnea histogram and breathing pattern introduced in this proposal and comprehensively discriminating both. 
Shirasuna, Zhang, Toda, Ishikawa, Sakaguchi and Akiduki, Transactions of the JSME (in Japanese), Vol.84, No.868 (2018)

\section{6. 結 言}

本稿では, 睡眠時の呼吸音データのみを対象として医工学的立場から, 簡易的な SAS の判別とその予備群の発 見プロセスの提案を行った。それらは以下のとおりである.

1.SAS の睡眠中の呼吸音から，無呼吸，呼吸リズムおよび高音圧の 3 つの特徵をあげ，これに着目した 5 段階 のSAS 罹患者と予備群の判別および早期発見プロセスの過程を示した.

2. 無音状態の秒数度数を視覚化するための, ヒストグラム作成した．また，このヒストグラムをもとに，SAS 予備群およびSAS の可能性についての定量評価が可能であることを示した.

3. 高音圧な睡眠中の呼吸音を抽出し，それをもとに呼吸パターンのクラスタ分析を行った．クラスタには 6 種 類のパターンがあることを示した。 そして，そのうち 3 種類のいずれかを持つ被験者については, SAS 予備 群および罹患者の可能性が高く疑われることを示した.

4. 上記の無音状態の秒数度数のヒストグラムおよび呼吸パターンのクラスタをもとに階層型クラスタ分析を行っ

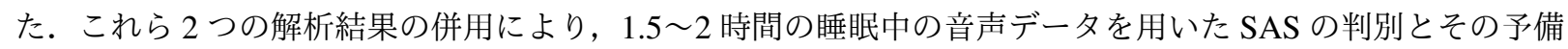
群発見のための総合判別が可能であることが示された.

今後は, より多くの被験者データ, 特に SAS 予備群の収集のもと, 解析精度の向上と検討に取り組みたい. 本 提案では，3つの解析手法を併用しているが，それ以外の解析手法についても，提案と検討を重㱛，特に定量的な 評価に関する考案が必要と思われる，また，医療機関，専門家のアドバイスを積極的に取り入れ，各内容および 過程の改善と改良を図りたい。さらには，汎用に向けた実用性への考察と検討を試みたい。

謝 辞

豊橋メイツ睡眠治療クリニックのご協力により, SAS 罹患者の睡眠中の音声データの録音および提供を賜れま したことに謝意を表します．また，本研究の一部は科研費基盤（C）（課題番号：26420387）の補助を受けたこと を付記し，謝意を表します。

\section{文献}

青木繁伸, R による統計解析, オーム社（2009）, pp. 188-195, 226-236.

ビショップ, C.M., Pattern Recognition and Machine Learning（Information Science and Statistics），シュプリンガー · ジャパン株式会社（2007）,pp. 33-34.

Dalmasso, F. and Prota, R., Snoring: analysis, measurement, clinical implications and applications, Eur Respir J, Vol. 9 , No. 1 (1996), pp. 146-159.

Emin, T., Akin, M, M. and Sezgin, N., Classification of sleep apnea by using wavelet transform and artificial neural networks, Expert Systems with Applications (2010） , pp. 1600-1607.

Emoto, T., Abeyratne, U.R., Kawano, K., Okada, T., Jinnouchi, O. and Kawata, I., Detection of sleep breathing sound based on artificial neural network analysis. Biomedical Signal Processing and Control (2017) , Vol. 41, pp. 81-89. 井手剛, 入門 機械学習による異常検知-Rによる実践ガイド, コロナ社（2015）, pp. 84-93, 114-116.

Kaneshiro, S., Mitsukura, Y. and Hamada, N., Respiratory sound analysis for continuous positive airway pressure machines, 2016 IEEE 12th International Colloquium on Signal Processing and Its Applications（CSPA）（2016）, DOI: $10.1109 /$ CSPA.2016.7515809.

Koley, B.L. and Dey, D., Classification of sleep apnea using cross wavelet transform. 2013 IEEE 1st International Conference on Condition Assessment Techniques in Electrical Systems (CATCON) (2013), DOI: 10.1109/CATCON.2013.6737512.

Kim, T., Kim, J. and Lee, K., Detection of sleep disordered breathing severity using acoustic biomarker and machine learning techniques. BioMedical Engineering OnLine (2018） , DOI: org/10.1186/s12938-018-0448-x.

国土交通省，「睡眠時無呼吸症候群」に注意しましょう！ （oneline）， available from <http://www.mlit.go.jp/kisha/kisha03/09/090318/090318.pdf>，（参照日 2018 年 08 月 08 日）。 
厚生労働省, 厚生労働省 生活習慣病予防のための健康情報サイト 睡眠時無呼吸症候群 $\mathrm{e}$-ヘルスネット 情報提供 （oneline）, available from <https://www.e-healthnet.mhlw.go.jp/information/heart/k-02-002.html>，（参照日 2018 年 08 月 08 日）.

MacQueen, J., Some methods for classification and analysis of multivariate observations, Berkeley Symp. on Math. Statist. and Prob. Proc. Fifth Berkeley Symp. on Math. Statist. and Prob., Vol. 1 Univ. of Calif. Press (1967）, pp. 281-297. 永田靖, 棟近雅彦, 多変量解析法入門 (ライブラリ新数学大系), サイエンス社 （2001）, pp. 97-117, 174-184.

Ng, A. K., Koh, T. S., Baey, E., Lee, T.H., Abeyratne, U.R. and Puvanendran, K., Could formant frequencies of snore signals be an alternative means for the diagnosis of obstructive sleep apnea?, Sleep Medicine 9 (2008), pp. 894-898.

Nishijima, K., Uenohara, S. and Furuya, K., Estimation of noise suppression parameters for maximizing snoring activity detection performance. Consumer Electronics - Taiwan （ICCE-TW）, 2017 IEEE International (2017) , DOI 10.1109/ICCE-China.2017.7990975.

Qian, K., Janott, C., Pandit, V., Zhang, Z., Heiser, C., Hohenhorst, W., Herzog, M., Hemmert, W. and Schuller, B., Classification of the Excitation Location of Snore Sounds in the Upper Airway by Acoustic Multi-Feature Analysis, IEEE Transactions on Biomedical Engineering. Vol.64, Issue.8 (2016), pp. 1731-1741, DOI: 10.1109/TBME.2016.2619675.

Rachim, V.P., Li, G. and Chung, W.Y., Sleep apnea classification using ECG-signal wavelet-PCA features, Biomed Mater Eng, Vol. 24, Issue 6 (2014) , pp. 2875-2882.

SAS 診療国際提供サービス・ビジネス化検証コンソーシアム. 日本式・睡眠時無呼吸症候群診療サービスの提供に 向けた実証調査報告書（2015）, p. 3.

佐藤公則, 睡眠時無呼吸症候群の診療メソッド - 睡眠呼吸障害の集学的治療, 中外医学社（2016）, pp. 5, 8-14, 23-36.

Shiomi, F.K., Pisa, I.T. and Campos, C., Computerized analysis of snoring in Sleep Apnea Syndrome. Brazilian journal of otorhinolaryngology, Vol. 77, No. 4 (2011) , DOI: 10.1590/S1808-8694201100040001.

塩見利明, 睡眠無呼吸症: 広がる SAS の診療, 朝倉書店 (2013), pp. 11-27.

白濱龍太郎, 図解 睡眠時無呼吸症候群を治す! 最新治療と正しい知識, 日東書院本社（2015）, pp. 22, 24-27.

数納聖冴, 神藤徳彦, 加藤優基, 中島弘史, 三好和憲. 睡眠時無呼吸症候群の簡易診断システムの構築のための音環境

調査とハードウェア要件の明確化 信学技報, Vol. 112, No. 478 （2013）, EA2012-141, pp. 1-6.

高橋宏明, 睡眠時呼吸障害-その診断と治療, 金芳堂（1993）, pp. 5, 65-92.

玉置淳, 全部見える呼吸器疾患-スーパービジュアル, 成美堂出版 (2013) , p. 51.

富田康弘, 成井浩司, 睡眠関連呼吸障害 - 睡眠時無呼吸症候群の検査, 臨床検査, Vol. 60, No.9（2016）, pp. 946-954. 内田直, 好きになる睡眠医学第 2 版, 講談社（2013）, pp. 79-83.

Zhanga, X. and Qiu, X., Performance of a snoring noise control system based on an active partition. Applied Acoustics, Vol. 116 (2017) , pp. 283-290.

\section{References}

Aoki, S., Statistical analysis by R, Ohm (2009) , pp. 188-195, 226-236(in Japanese).

Bishop, C.M., Pattern Recognition and Machine Learning (Information Science and Statistics), Springer (2006), pp.33-34 (in Japanese).

Dalmasso, F. and Prota, R., Snoring: analysis, measurement, clinical implications and applications, Eur Respir J, Vol. 9 , No. 1 (1996) , pp. 146-159.

Emin, T., Akin, M, M. and Sezgin, N., Classification of sleep apnea by using wavelet transform and artificial neural networks, Expert Systems with Applications （2010） , pp. 1600-1607.

Emoto, T., Abeyratne, U.R., Kawano, K., Okada, T., Jinnouchi, O. and Kawata, I., Detection of sleep breathing sound based on artificial neural network analysis. Biomedical Signal Processing and Control (2017) , Vol. 41, pp. 81-89.

Ide, T., Anomaly detection by introductory machine learning - practical guide by R, Coron （2015）, pp. 84-93, 114-116 (in Japanese).

Kaneshiro, S., Mitsukura, Y. and Hamada, N., Respiratory sound analysis for continuous positive airway pressure machines, 2016 IEEE 12th International Colloquium on Signal Processing and Its Applications（CSPA）（2016）, 
DOI: $10.1109 /$ CSPA.2016.7515809.

Koley, B.L. and Dey, D., Classification of sleep apnea using cross wavelet transform. 2013 IEEE 1st International Conference on Condition Assessment Techniques in Electrical Systems (CATCON) (2013), DOI: 10.1109/CATCON.2013.6737512.

Kim, T., Kim, J. and Lee, K., Detection of sleep disordered breathing severity using acoustic biomarker and machine learning techniques. BioMedical Engineering OnLine (2018), DOI: org/10.1186/s12938-018-0448-x.

Ministry of Land, Infrastructure, Transport and Tourism, "Let's be careful, Sleep Apnes Syndrome” (oneline) , available from < http://www.mlit.go.jp/kisha/kisha03/09/090318/090318.pdf>, （Reference day 2018/08/08） (in Japanese).

Ministry of Health, Ministry of Health Healthy information site for the lifestyle-related disease prevention Sleep Apnea Syndorome e-HealthNet Information dissemination (oneline), available from <https://www.ehealthnet.mhlw.go.jp/information/heart/k-02-002.html>, （Reference day 2018/08/08） (in Japanese).

MacQueen, J., Some methods for classification and analysis of multivariate observations, Berkeley Symp. on Math. Statist. and Prob. Proc. Fifth Berkeley Symp. on Math. Statist. and Prob., Vol. 1 Univ. of Calif. Press (1967）, pp. $281-297$.

Nagata, Y., Munechika, M., Introduction to multivariate analysis method (Library New mathematicians major) (2001) , Science, pp. 97-117, 174-184 (in Japanese).

Ng, A. K., Koh, T. S., Baey, E., Lee, T.H., Abeyratne, U.R. and Puvanendran, K., Could formant frequencies of snore signals be an alternative means for the diagnosis of obstructive sleep apnea?, Sleep Medicine 9 (2008), pp. 894-898.

Nishijima, K., Uenohara, S. and Furuya, K., Estimation of noise suppression parameters for maximizing snoring activity detection performance. Consumer Electronics - Taiwan （ICCE-TW）, 2017 IEEE International (2017), DOI 10.1109/ICCE-China.2017.7990975.

Qian, K., Janott, C., Pandit, V., Zhang, Z., Heiser, C., Hohenhorst, W., Herzog, M., Hemmert, W. and Schuller, B., Classification of the Excitation Location of Snore Sounds in the Upper Airway by Acoustic Multi-Feature Analysis, IEEE Transactions on Biomedical Engineering. Vol.64, Issue.8 (2016), pp. 1731-1741, DOI: 10.1109/TBME.2016.2619675.

Rachim, V. P., Li, G. and Chung, W. Y., Sleep apnea classification using ECG-signal wavelet-PCA features, Biomed Mater Eng, Vol. 24, Issue 6 (2014) , pp. 2875-2882.

SAS Medical service international offering service $\cdot$ Businessization verification consortium. Japanese style $\cdot$ Empirical research report for providing Sleep Apnea Syndrome medical service (2015) , p. 3 (in Japanese).

Sato, K., Clinical method of Sleep Apnea Syndrome - Multidisciplinary treatment of sleep disordered breathing, CyugaiIgaku (2016), pp. 5, 8-14, 23-36 (in Japanese).

Shiomi, F.K., Pisa, I.T. and Campos, C., Computerized analysis of snoring in Sleep Apnea Syndrome. Brazilian journal of otorhinolaryngology, Vol. 77, No. 4 (2011) , DOI: 10.1590/S1808-8694201100040001.

Shiomi, T., Seep Apnea Syndorome: Medical treatment of spreading SAS, Askura Shoten (2013) , pp. 11-27 (in Japanese).

Shirahama, R., Illustration cure sleep apnea syndrome! Recent treatment and correct knowledge, Nitto Shoin Honsya (2015) , pp. 22, 24-27 (in Japanese).

Suno, S., Shindo, T., Kato, Y.,Nakajima,H. and Miyoshi, K., Clarification of sound environmental research and hardware requirements for the construction of a simple diagnostic system sleep apnea syndrome, Shingaku Giho, Vol. 112, No. 478 (2013) , EA2012-141, pp. 1-6 (in Japanese).

Takahashi, H., Sleep Apnea Syndorome - Its diagnosis and treatment, Kinpodo （1993）, pp. 5, 65-92 (in Japanese).

Tamaoki, J., All visible respiratory diseases - Supervisual, Anrumido Syuppan （2013）, p. 51 (in Japanese).

Tomita, Y. and Narui, K., Sleep Apna Syndorome - Inspection of sleep apnea syndrom and clinical examination, Clinical examination, Vol. 60, No.9 (2016), pp. 946-954 (in Japanese).

Uchida, N., Sleeping medicine that you like 2nd, Kodansya (2013), pp. 79-83 (in Japanese).

Zhanga, X. and Qiu, X., Performance of a snoring noise control system based on an active partition. Applied Acoustics, Vol. 116 (2017), pp. 283-290. 